\title{
Unilateral spontaneous adrenal hemorrhage in a young patient
}

\author{
Muhammet Ferhat Çelik, M.D., Cevher Akarsu, M.D., Ahmet Cem Dural, M.D., \\ Murat Çikot, M.D., Mustafa Gökhan Ünsal, M.D., Halil Alış, M.D.
}

Department of General Surgery, Bakirkoy Dr. Sadi Konuk Training and Research Hospital, İstanbul

\begin{abstract}
The objective of this study was to report an unusual case of unilateral adrenal hematoma in; a I9-year-old young man who did not have a history of any specific systemic disease. The patient was admitted to hospital with chest pain that lasted for one day. Preoperative contrast-enhanced computerized tomography evaluated an adrenal mass (sized, $10.5 \times 12.7 \mathrm{~cm}$ ) adjacent to the anterior of the left kidney, and findings were indicative of adrenal hematoma. The final pathological diagnosis was adrenal adenoma.
\end{abstract}

Key words: Adrenal gland; adrenal hematoma; adrenal hemorrhage.

\section{INTRODUCTION}

Adrenal hemorrhage $(\mathrm{AH})$ can result from a variety of reasons. The large majority of patients with unilateral adrenal hemorrhage do not have clinically obvious signs of adrenal insufficiency, and diagnosis is usually made incidentally by the imaging performed for another reason. When unilateral, it is often clinically silent. ${ }^{\left[{ }^{I]}\right.}$

Adrenal hemorrhage is associated with not only meningococcal septicemia but also disseminated intravascular coagulation (Waterhouse-Friderichsen syndrome); however, trauma, complications of pregnancy, tumors, surgical stress or anticoagulation therapy may also cause AH. ${ }^{[2]}$ Primary adrenal cortical neoplasm rarely presents with spontaneous retroperitoneal hemorrhage. Nonetheless, spontaneous or idiopathic, $\mathrm{AH}$ is extremely rare in adults. ${ }^{[2]}$

This article reported the case of a young patient with spontaneous unilateral adrenal hemorrhage.

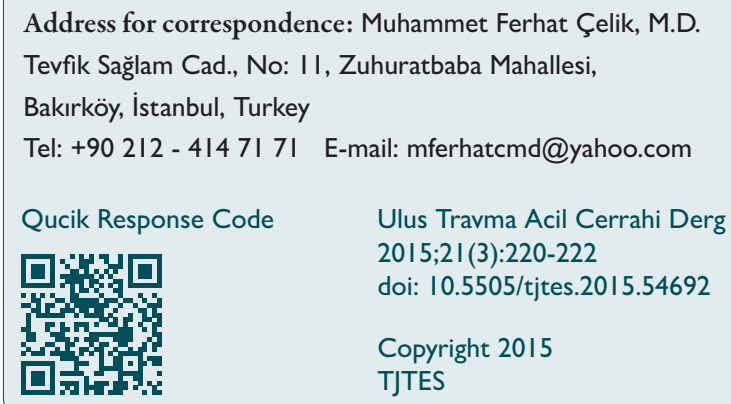

\section{CASE REPORT}

A 19-year-old man was admitted to hospital for acute chest pain and generalized weakness that continued for one day. There was no history of abdominal trauma, fever, hematuria, urinary symptoms or any specific systemic disease. On examination, the patient had tachycardia (120 beats per minute), but his blood pressure was normal. The patient had normal abdominal examination except for mild abdominal distension. Hematological investigation revealed severe anemia (hemoglobin $6.8 \mathrm{~g} / \mathrm{dL}$ ) with decreased hematocrit $(23.2 \%)$ and neutrophilic leukocytosis $\left(19800 / \mathrm{mm}^{3}\right)$. Routine urine examination revealed 2 red blood cells and 10 pus cells/high power field (HPF). The coagulation profile as well as the serum amylase and lipase levels were normal. Abdominal ultrasound revealed diffuse free liquid into the peritoneal cavity. A computerized tomography (CT) scan of the abdomen was performed, which showed a left-sided perirenal solid mass and hematoma suggestive of renal origin in size of $10.5 \times 12.7$ $\mathrm{cm}$ (Fig. I). The endocrinological examinations of the patient revealed Aldosterone $23.1 \mathrm{~g} / \mathrm{dL}$ and Cortisol $34.6 \mu \mathrm{g} / \mathrm{dL}$.

Preoperatively, six bags of erythrocyte suspension and four bags of fresh frozen plasma was transfused to the patient. An emergency operation was performed due to the worsening of the patient's general condition on day three. A laparotomic left adrenalectomy and drainage of the hematoma was performed. The excised specimen contained an adenoma of the adrenal gland (Fig. 2). Postoperative recuperation was uneventful. Therefore, the final pathological diagnosis was adrenal adenoma. This study reported a case of spontaneous $\mathrm{AH}$ in a young man. 

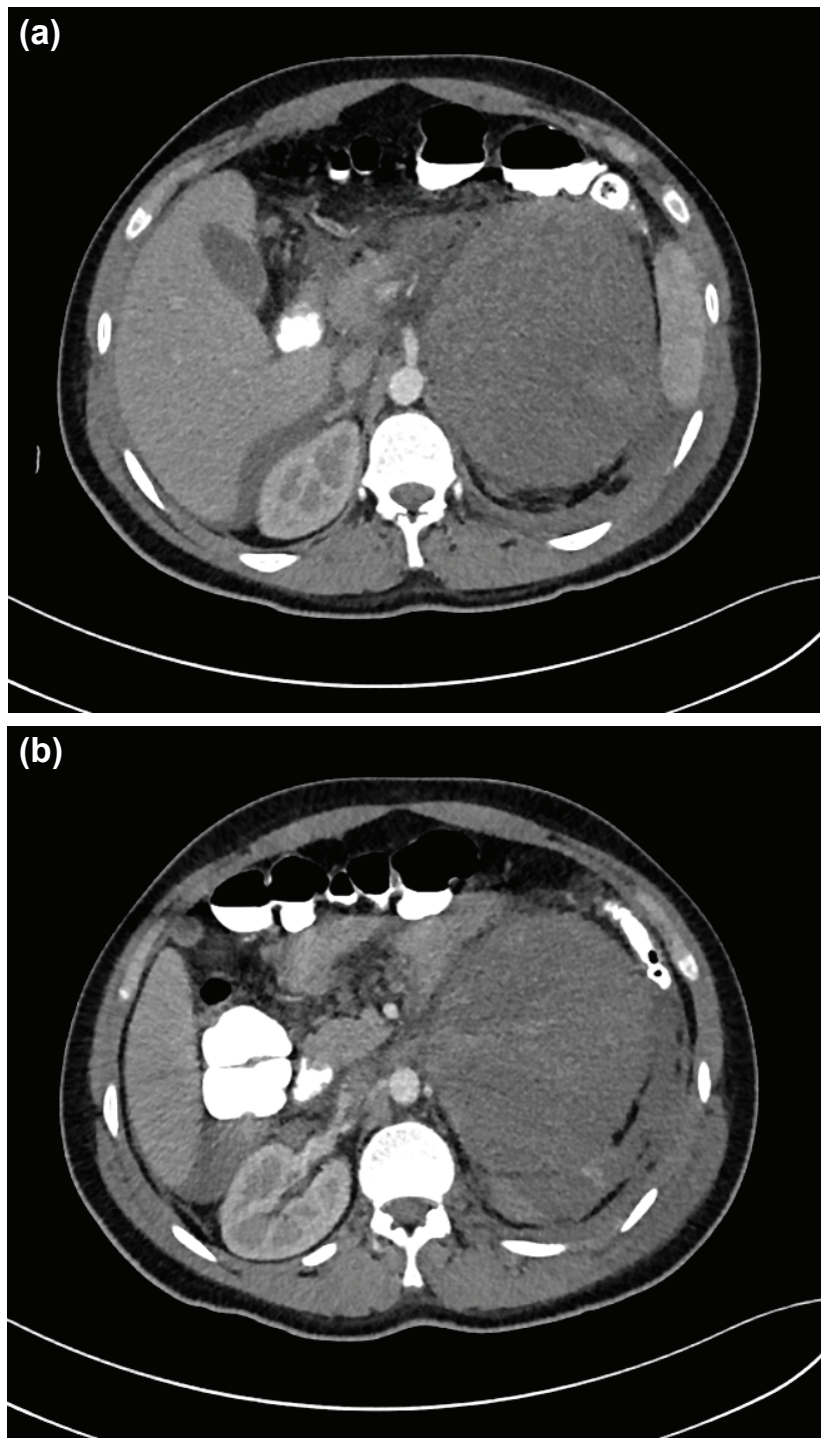

Figure 1. (a, b) Computerized tomography scan of the abdomen.

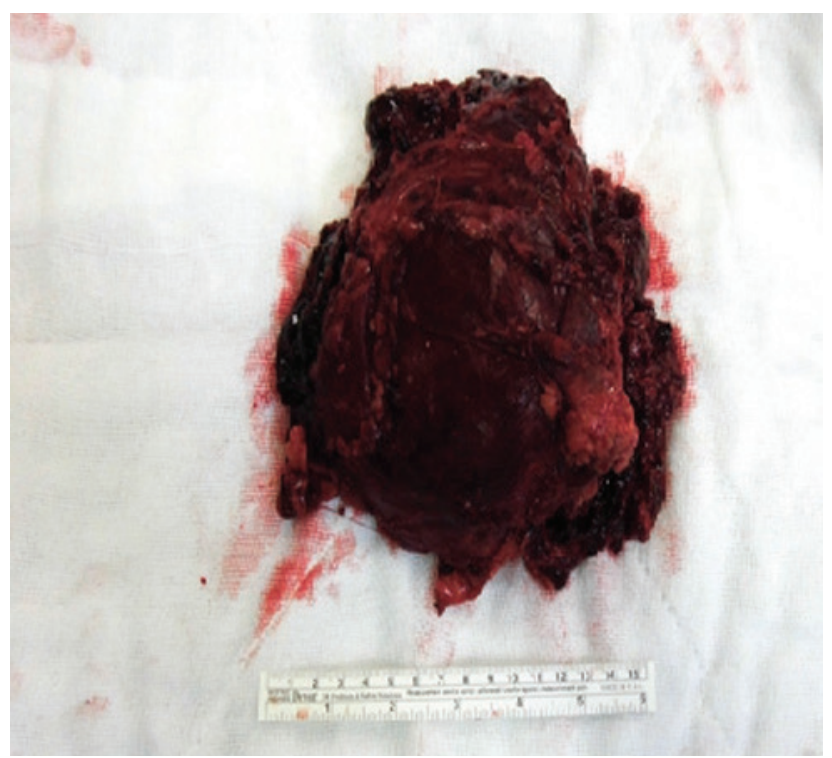

Figure 2. Macroscopic imaging of the excised specimen.

\section{DISCUSSION}

Common etiologies of spontaneous retroperitoneal hemorrhage in adults include trauma, coagulopathy or anticoagulation therapy, ruptured aneurysm of the aorta, splenic or renal artery and an arteriovenous malformation. ${ }^{[3]}$ Spontaneous or idiopathic adrenal hemorrhage is extremely rare in adults. The incidence of spontaneous $\mathrm{AH}$ has been reported between $0.14 \%$ and I.I\%, usually involving the right gland. ${ }^{[4]}$ Spontaneous hemorrhage can also occur in the retroperitoneum.

Adrenal hematomas have numerous and highly dissimilar radiographic appearances in CT. Magnetic resonance imaging is an alternative imaging modality for characterization of adrenal masses including adrenal hemorrhage. ${ }^{[5]}$

Since the 1990s, open adrenalectomy has been replaced with laparoscopic adrenalectomy (LA), and the implementation of minimally invasive surgery in adrenal gland surgery has gained significant momentum. Currently, LA has become a standard surgical method in many centers. ${ }^{[6]}$

$\mathrm{AH}$ rarely results from ruptured adrenal neoplasm. $\mathrm{AH}$ from a malignant primary adrenal neoplasm is also rare. ${ }^{[3]}$ Adrenocortical carcinoma is a rare malignancy with an annual incidence of $\mathrm{I}-2 /$ million. ${ }^{[7]} \mathrm{It}$ is common in the fifth decade of life and in children under the age of $5 .{ }^{[8]}$

Baksi et al. ${ }^{[3]}$ have presented a similar case with spontaneous retroperitoneal hemorrhage in a 21 -year-old woman. Histological examination of the resected specimen has revealed an adrenocortical neoplasm.

Patients with hemorrhage usually do not present with hemorrhagic shock. Initially, they can be managed conservatively and investigated prior to surgery.

Our patient had no fever, neck stiffness, findings of meningitis and meningococcal septicemia; and therefore, these diseases were excluded.

Endocrinological examinations could not be fully carried out as an emergency surgery had to be performed in the preoperative preparation stage. In addition, it was initially thought as having renal origin. Possible differential diagnoses included a ruptured splenic or renal vascular aneurysm, an arteriovenous malformation or an adrenal vascular lesion. In this regard, angio-embolization of the bleeding adrenal vessels was reported. ${ }^{[9]}$ Interventional radiology concluded that embolization was not suitable for the patient as the bleeding came from the mass. In a retrospective study of one hundred and forty-one patients of spontaneous $\mathrm{AH}$ admitted in the Mayo Clinic, College of Medicine from 1972 to 1997, sixteen patients presented with sudden abdominal pain and unilateral $\mathrm{AH}$, and only seven required surgery in order to control the 
retroperitoneal hemorrhage associated with the hemorrhagic adrenal gland, just like in our patient. ${ }^{[2]}$

The possibility of $\mathrm{AH}$ should be kept in mind for acute abdominal pain, especially in patients with a diagnosis of a perirenal hematoma upon imaging. It can be concluded that in clinically stable patients, preoperative investigation and diagnosis can be performed in detail with a conservative approach.

\section{Conflict of interest: None declared.}

\section{REFERENCES}

1. Imachi H, Murao K, Yoshimoto T, Sugimoto M, Kakehi Y, Hayashi $\mathrm{T}$, et al. Idiopathic unilateral adrenal hemorrhage in an elderly patient. Endocrine 2010;37:249-52. CrossRef

2. Vella A, Nippoldt TB, Morris JC 3rd. Adrenal hemorrhage: a 25-year experience at the Mayo Clinic. Mayo Clin Proc 2001;76:161-8. CrossRef

3. Baksi A, Gupta S, Ray U, Ghosh S. Spontaneous retroperitoneal haem- orrhage in a young adult. BMJ Case Rep 2014;2014.

4. Gavrilova-Jordan L, Edmister WB, Farrell MA, Watson WJ. Spontaneous adrenal hemorrhage during pregnancy: a review of the literature and a case report of successful conservative management. Obstet Gynecol Surv 2005;60:191-5. CrossRef

5. Sacerdote MG, Johnson PT, Fishman EK. CT of the adrenal gland: the many faces of adrenal hemorrhage. Emerg Radiol 2012;19:53-60. CrossRef

6. Akarsu C, Dural AC, Kankaya B, Çelik MF, Köneș O, Mert M, et al. Robotik adrenalektomide başlangıç deneyim ve ilk sonuçlarımız. Ulusal Cer Derg 2014;30:28-33.

7. Schteingart DE, Doherty GM, Gauger PG, Giordano TJ, Hammer GD, Korobkin M, et al. Management of patients with adrenal cancer: recommendations of an international consensus conference. Endocr Relat Cancer 2005;12:667-80. CrossRef

8. Yeh MW, Duh QY. The adrenal glands. In: Townsend CM Jr, ed. Sabiston text book of surgery: the biological basis of modern surgical practice, 19th ed. Philadelphia: Saunders, Elsevier; 2012. p. 979-80. CrossRef

9. Nakajo M, Onohara S, Shinmura K, Fujiyoshi F, Nakajo M. Embolization for spontaneous retroperitoneal hemorrhage from adrenal myelolipoma. Radiat Med 2003;21:214-9.

\section{OLGU SUNUMU - ÖZET}

\section{Genç hastada spontan tek taraflı adrenal kanama}

Dr. Muhammet Ferhat Çelik, Dr. Cevher Akarsu, Dr. Ahmet Cem Dural, Dr. Murat Çikot, Dr. Mustafa Gökhan Ünsal, Dr. Halil Alış

Bakırköy Dr. Sadi Konuk Eğitim ve Araştırma Hastanesi, Genel Cerrahi Kliniği, İstanbul

Bu yazıda, herhangi bir spesifik sistemik hastalık öyküsü olmayan 19 yaşında genç bir hastada, nadir görülen tek taraflı adrenal hematomu sunuldu. Hasta bir gündür olan göğüs ağrısı şikayeti ile acil servise başvurdu. Ameliyat öncesi dönemde yapılan değerlendirmede çekilen kontrastlı bilgisayarlı tomografi sonucunda sol böbrek komşuluğunda $10.5 \times 12.7 \mathrm{~cm}$ adrenal kitle ve hematom saptandı. Ameliyat sonrası kitlenin patolojik incelemesinde adrenal adenom saptandı.

Anahtar sözcükler: Adrenal bez; adrenal hemoraji; adrenal hematom.

Ulus Travma Acil Cerrahi Derg 20I5;2I (3):220-222 doi: 10.5505/tjtes.20I5.54692 